\title{
Implementasi Peraturan Bupati Kabupaten Aceh Jaya Nomor 21 Tahun 2011 Tentang Penataan Pertambangan Emas Rakyat
}

\author{
Aminah, Effendi Hasan, Ubaidullah \\ Universitas Syiah Kuala, Banda Aceh, 23111, Indonesia
}

\begin{tabular}{|c|c|}
\hline ARTICLE INFORMATION & A B S T R A C T \\
\hline $\begin{array}{l}\text { Received: February 11, } 2021 \\
\text { Revised: March 05, } 2021 \\
\text { Accepted: April 18, } 2021 \\
\text { Available online: April 25, } 2021\end{array}$ & $\begin{array}{l}\text { The development of gold for the people of Aceh Jaya district has had a wide impact on the community around } \\
\text { the mining area. Therefore, the Aceh Jaya district government has enacted regent regulation no } 21 \text { of } 2011 \\
\text { regarding the arrangement of community mining, but the policy implementation has not been optimal. The } \\
\text { research was peeled off using implementation models from Smith as well as Van Metter and Van Horn. This }\end{array}$ \\
\hline KEYWORDS & $\begin{array}{l}\text { study aims to analyze the implementation of Aceh Jaya government policies in structuring community gold } \\
\text { mining in Gunong Ujeun village, Krueng Sabee sub-district, Aceh Jaya district. This research uses a qualitative }\end{array}$ \\
\hline Implementation, Policy and Mining & $\begin{array}{l}\text { method, namely by interviewing informants. The results of the study illustrate that the implementation of the } \\
\text { policy or regional regulation of Aceh Jaya district number } 21 \text { of } 2011 \text { has not been running optimally. This can }\end{array}$ \\
\hline CORRESPONDENCE & $\begin{array}{l}\text { be seen from the number of miners who do not know the existence of the regulations set by the government. In } \\
\text { addition, the lack of monitoring on the part of the government has also resulted in community gold mining in }\end{array}$ \\
\hline $\begin{array}{l}\text { Phone: +6285370328875 } \\
\text { E-mail: aminah@unsyiah.ac.id }\end{array}$ & $\begin{array}{l}\text { Gunong Ujeun being continuously mining illegally by the community, either individually or through } \\
\text { established cooperatives. }\end{array}$ \\
\hline
\end{tabular}

\section{PENDAHULUAN}

Pertambangan merupakan proses dari sebagian kegiatan atau seluruh tahapan yang dilakukan mulai dari penyelidikan umum, eksplorasi, studi kelayakan hingga proses kegiatan pasca tambang (Djajadiningrat, 2007; Widagdya, 2014; Sularno, 2019). Negara Indonesia dapat dikatakan sebagai salah satu negara yang memiliki aneka kekayaan alam yang dapat dijadikan sebagai sebagai sumber untuk meningkatkan taraf kehidupan masyarakat (Rochmaningrum, 2012).

Sumber daya alam dalam hal ini pertambangan menjadi salah satu andalan negara Indonesia setelah sektor pertanian (Andriani, 2018). Hal ini membuktikan bahwa sektor prtambangan memiliki posisi penting dalam hal meningkatkan pendapatan masyarakat, perusahaan bahkan negara. Terdapat berbagai peraturan yang mengatur tentang pertambangan ,baik berupa undang-undang, peraturan Presiden, keputusan menteri, peraturan pemerintah, bahkan hingga Peraturan bupati. Seperti halnya yang terjadi di Kabupaten Aceh Jaya, pada tahun 2008, sejak ditemukannya bebatuan yang mengandung emas di dalamnya yang terletak di Gunong Ujeun Kabupaten Aceh Jaya, wilayah ini di datangi oleh banyak orang (penambang) yang berasal dari berbagai daerah untuk melakukan penambangan emas (Aminah, 2019). Hal ini mengharuskan pemerintah kabupaten Aceh Jaya untuk membentuk peraturan tentang penambangan emas rakyat untuk menjaga keseimbangan dan menghindari konflik serta kerusakan lingkungan (Aminah, 2017; Aminah, 2015; Yudhistira, 2011). Miftah Thoha telah menegaskan bahwa kebijakan (policy) adalah suatu keputusan yang diambil oleh pemerintah yang didasarkan pada kejadian yang timbul dalam masyarakat, guna untuk memenuhi kepentingan masyarakat itu sendiri (Thoha, M, 2005). Kebijakan publik juga dapat diartikan sebagai sutu visi dan misi (tujuan) yang telah disepakati bersama (Nugroho, 2004).

Dalam perkembangannya, di tahun 2011 proses penambangan emas semakin marak dilakukan. Dalam menangani permasalahan tersebut, pemerintah Kabupaten Aceh Jaya telah membuat sebuah aturan yang dituangkan melalui Peraturan Bupati Aceh Jaya Nomor 21 Tahun 2011 tentang Penataan Pertambangan Rakyat. Dalam aturan tersebut telah mengatur berbagai tata cara dalam proses penambangan emas rakyat mulai dari persyaratan yang harus dipenuhi hingga masalah pencemaran lingkungan.

Secara teori Dye telah mengatakan bahwa "whatever government chooses to do or not to do" yang dapat diartikan bahwa kebijakan sebagai sebuah pilihan bagi pemerintah untuk melakukan ataupun tidak melakukan sesuatu (Dye, 1992; Winarno, B, 2007). Selanjutnya Wahab juga mengutarakan bahwa kebijakan adalah suatu tindakan yang dapat mengarah pada suatu tujuan yang diusulkan (Wahab, 2006). Adapun Sasaran yang diharapkan dengan adanya Perbup yang telah ditetapkan oleh pemerintah kabupaten Aceh Jaya yaitu seluruh para penambang emas di wilayah Gunong Ujeun dan wilayah pertambangan lainnya di kabupaten Aceh Jaya yang dapat meningkan Pendapatan Asli Daerah (PAD) serta menjaga kualitas lingkungan terutama di Daerah Aliran Sungai (DAS) Krueng Sabee. Namun, meskipun pemerintah kabupaten Aceh Jaya telah mengeluarkan Perbup tersebut, namun sampai saat ini dapat dilihat bahwa masih tetap terjadi penambangan emas secara illegal serta masih banyak terdapat kesenjangan sosial dalam masyarakat. Lubang-lubang tempat penambangan emas dilakukan telah merusak ekosistem hutan, yang mengakibatkan serinya terjadi banjir di wilayah kecamatan Krueng Sabee dan Kecamatan Panga di setiap tahunnya. 
Dalam menjalankan atau mengimplementasikan terkait dengan telah diukur oleh Smith (1973), menurutnya "The context of the implementation of policies the policy relevant components which form the tension generating matrix. I wish to identify four such component which are important in the policy implementation process :

a. The idealized policy (kebijakan Ideal)

b. The target groups (Kelompok Sasaran)

c. The implementing organization (Badan-Badan Pelaksana)

d. The environmental factor (faktor Lingkungan)

Berdasarkan permasalahan tersebut, maka yang menjadi rumusan masalah dalam penelitian ini yaitu bagaimana implementasi kebijakan pemerintah kabupaten Aceh Jaya dalam penataan pertambangan emas rakyat di Gunong Ujeun?

\section{METODE}

Metode Penelitian yang menggunakan adalah metode kualitatif. Metode kualitatif menghasilkan data deskriptif, baik berupa kata-kata, yang diungkapkan secara tulisan maupun lisan dari perilaku yang diamati (Moleong, 2010; Bungin, 2007; Denzin, 2010). Pengumpulan data dilakukan dengan observasi dan wawancara secara semi terstruktur terhadap para informan penelitian.

Penentuan para Informan dilakukan dengan metode purporsive sampling, dalam hal ini proses penentuan para informan dilakukan secara acak dengan pertimbanganpertimbangan tertentu yang ditetapkan oleh peneliti. Adapun yang menjadi informan dalam penelitian ini yaitu pemerintah kabupaten Aceh Jaya, Ketua Bidang pertambangan Kabupaten Aceh Jaya, Camat Krueng Sabee, Gethjik Gampong Panggong dan para penambang baik yang bekerja secara perseorangan (dua orang) maupun secara kelompok melalui Koperasi (dua orang). Sedangkan teknik analisis data yang digunakan dalam penelitian ini yaitu data yang telah terkumpul selanjutnya diolah dan dianalisis secara kualitatif.

\section{HASIL DAN PEMBAHASAN}

Berdasarkan teori yang digunakan dalam penelitian ini tentang teori implementasi dari Smith bahwa dalam imlementasi terdapat empat variable yaitu The idealized policy (kebijakan Ideal), The target groups (Kelompok Sasaran), The implementing organization (Badan-Badan Pelaksana) dan The environmental factor (faktor Lingkungan). Dalam hal ini, Pemerintah kabupaten Aceh Jaya dalam mejalankan implementasi terhadap Perbup Kabupaten Aceh Jaya Nomor 21 Tentang Penataan Pertambangan Rakyat masih belum berjalan dengan maksimal. Hal ini dapat digambarkan dari berbagai fakta bahwa, sampai saat ini masyarakat masih terus melakukan proses penambangan emas di Gunong UJeun tanpa memperhatikan kondisi lingkungan dan dampak yang akan diterima oleh masyarakat disekitar wilayah pertambangan. Disamping itu, pihak pemerintah juga kurang melakukan pengawasan terhadap proses penambangan yang dilakukan baik oleh masyarakat secara perseorangan maupun yang dilakukan secara kelompok melalui koperasi-koperasi yang telah dibentuk. Hal ini seperti yang diungkapkan oleh Jullasmi salah satu penambang Koperasi, berikut adalah hasil wawancarannya:

"Sampai saat ini kami masih melakukan penambangan diwilayah Gunong Ujeun, kita terus menggali lobang lobang yang kita anggap masih memiliki kadar emas yang tinggi, kita juga semua masih tetap berjalan seperti biasanya dan pihak pemerintah juga tidak pernah turun lagi ke lapangan. Dulu iya pernah mengecek proses pertambangan disini. Tapi beberapa tahun terakhir ini tidak pernah lagi ke lokasi pertambangan" (Jullasmi, 26 Oktober 2020).

Hal yang sama juga diungkapkan oleh Ramli DU salah satu penambang perseorangan, berikut adalah hasil wawancarannya:

"Saat ini pertambangan rakyat ini masih aman-aman saja. belum ada tindak lanjut dari pemerintah terkait dengan pengelolaannya, kondisi dilapangan masih sama seperti sebelumnya. Aktivitasnya juga masih stabil dan dalam dua tahun terakhir ini bahkan belum pernah dikunjungi lagi oleh pemerintah. Kalau dulu pas booming tentang Gunong Ujeun iya ramai pihak pemerintah kesana bahkan beberapa teman kita pernah diberikan sosialisasi tentang peraturan bupati dalam penataan pertambangan emas rakyat. Namun tidak semua kita diberikan sosialisasi itu" (Ramli DU, 26 Oktober 2020)

Terkait dengan hal itu, pihak pemerintah (Kepala Dinas Kehutanan kabupaten Aceh Jaya) juga memberikan pendapatnya, berikut adalah hasil wawancaranya:

"Memang Saat ini pertambangan rakyat di Gunong Ujeun masih tetap berjalan. Namun tidak seperti pada awal-awal pertambangan itu dimulai. Kalau dulu heboh dan penggilingan emas juga ada dimana-mana, sekarang tempat penggilingan lebih teratur. Kalau terkait dengan wilayah pertambangan memang dalam beberapa tahun terakhir ini kita belum kesana. Tapi ya pasti pertambangan apapun dilakukan tetap akan merusak lingkungan. Ya kita berharap masyarakat kita tetap mematuhi terhadap aturan yang telah ditetapkan oleh pemerintah" (Muchtar, wawancara 18 Oktober 2020).

Berdasarkan hasil temuan dilapangan dapat dilihat bahwa the idealized policy seperti yang Smith ungkapkan belum bisa berjalan dalam implementasi peraturan bupati No 21 Tahun 2011 tentang penataan pertambangan emas rakyat di kabupaten Aceh Jaya. Hal ini juga mengakibatkan kerugian bagi pemerintah sehingga tidak memiliki PAD dari hasil tambang emas tersebut.

Selain itu, tidak adanya laporan dari masyarakat dan penambang kepada pemerintah juga tidak terlaksana dengan baik, masyarakat yang menambang tidak membuat laporan secara kontinu kepada pemerintah terkait dengan kondisi lingkungan hutan disekitar wilayah penambangan. Dalam hal ini dapat dilihat bahwa masyarakat yang melakukan proses penambangan emas di daerah pertambangan Gunong Ujeun masih acuh tak acuh terhadap lingkungan kerjanya. Disisi lainnya, dalam mengimplementasikan kebijakan juga membutuhkan hadirnya suatu bentuk interaksi sosial yang menjadi sebagai bagian dari suatu proses dari implementasi kebijakan.

Proses implementasi kebijakan tidak berjalan dengan sendirinya setelah dikeluarkan kebijakan tersebut, pihak pemerintah perlu melakukan sosialisasi kepada masyarakat penambang bahkan hingga pada tahap pembinaan bahkan hingga tahap evaluasi terhadap suatu aturan atau kebijakn yang telah ditetapkan. Dari hal itu, tentunya akan diketahui sejauh 
mana kebijakan tersebut dapat dijalankan atau diimplementasikan. Sehingga kebijakan pemerintah kabupaten Aceh Jaya akan memberikan hasil atau dampak yang positif bagi lingkungan.

Adapun the target group (target grup) yang dari ditetapkannya pada Perbup Nomor 21 tersebut adalah para penambang yang melakukan penambangan emas di Kawasan Gunong Ujeun khususnya dan penambangan lainnya yang ada di Kabupaten Aceh Jaya baik dengan melakukan penambangan secara perseorangan maupun melakukannya secara kelompok melaui koperasi-koperasi yang ada. Para penambang sebagai target dari proses implementasikan suatu kebijakan dalam hal ini Perbup Nomor 21 tentu diminta untuk ikut berpartisipasi secara aktif dalam menjaga lingkungan dengan menaati terhadap peraturan yang berlaku.

Bentuk partisipasi aktif dari masyarakat penambang tentunya sangat penting terutama bagi pemerintah dalam mengatasi berbagai permasalan yang dimungkinkan akan terjadi dapat diminimalisir dan diantisipasi secara dini. Dampak yang akan dihasilkan dari penambangan emas di Gunong Ujeun adalah dampak lingkungan dalam hal ini lubang-lubang yang telah dibentuk oleh para penambang dapat merusak struktur tanah dan bahkan dapat mengakibatkan longsor dan juga banjir. Hal ini tentunya akan berakibat fatal pada kerusakan berbagai fasilitas umum seperti jalan, jembatan dan bahkan rumah warga sekitar wilayah pertambangan.

Laporan masyarakat penambang terhadap pihak pemerintah terkait dengan kondisi lingkungan di wilayah pertambangan dapat menjadi sebagai salah satu bahan pertimbangan bagi pemerintah dalam mengambil/menentukan langkah-langkah atau upaya yang akan diambil dalam menangani berbagai permasalahan yang terjadi dilapangan, sehingga lingkungan dapat terjaga. Saat ini, hasil penelitian dilapangan menunjukkan bahwa fungsi informasi belum dapat dijalankan dengan baik sebagaimana semestinya, hal ini dikarenakan pihak masyarakat penambang tidak mau melaporkan karena ditakutkan proses penambangan emas akan dihentikan oleh pihak pemerintah. Hal ini seperti yang diungkapkan oleh Rahmat salah satu penambang perseorangan. Berikut adalah hasil wawancaranya:

"kita sebagai masyarakat penambang tentu tidak akan melaporkan terkait dengan aktivitas penambangan kita. Yang ada nanti malahan akan dihentikan proses penambangan ini. Sementara kita mencari makan dari hasil tambang itu" (Rahmat, 26 Oktober 2020).

Hal yang sama juga diungkapkan oleh Jullasmi. Berikut adalah hasil wawancaranya:

"ya selama ini kita tidak pernah diminta untuk melaporkan terkait dengan aktivitas tambang disana. Selama ini kita beraktivitas seperti biasa. Kita juga tidak mungkin melaporkan jika pihak pemerintah tidak meminta laporan. Nanti malah dihentingan aktivitas pertambangan kita" (Jullasmi, 26 Oktober 2020).

Berdasarkan hasil wawancara tersebut dapat disimpulkan bahwa dalam proses menetapkan target grup dalam hal ini para penambang sebagai target group dari suatu kebijakan juga harus diperhatikan oleh pihak pemerintah. Dalam hal ini, kebijakan yang telah ditetapkan oleh pemerintah untuk dapat diterima serta menyesuaikan diri sebagai target dari kebijakan, karakteristik para penambang juga perlu dipelajari oleh pihak implementator, sehingga kebijakan yang disosialisasikan oleh pihak pemerintah dapat diterima dengan baik oleh pihak target group.

Dalam hal implementing Organization, Selain melihat karakteristik para penambang, para implementator juga harus memiliki kemampuan berkomunikasi yang baik. hal ini seperti yang dijelaskan oleh Tangkilisan bahwa suatu kebijakan harus diimplementasikan secara tepat dan ukuran implementisi bukan hanya diterima tetapi juga harus jelas (Tangkilisan, 2003). Dalam hal ini, pemerintah kabupaten Aceh Jaya telah menerbitkan aturan tentang penataan pertambangan emas rakyat di Gunong Ujeun. Dalam aturan tersebut telah disebutkan secara jelas terkait dengan hak, kewajiban dan larangan bagi para penambang baik secara perseorangan maupun secara koperasi. Selain itu, kurangnya sumber daya manusia sebagai para implementator juga menjadi suatu permasalahan yang serius. Hal ini dikarenakan, sumber daya manusia menjadi peran penting sebagai pelaksana dalam proses implementasi suatu kebijakan. Meskipun suatu organisasi memiliki berbagai sarana dan juga prasarana namun tanpa adanya sumber daya manusia akan sangat sulit dalam menjalankan kerja dengan baik. Hal ini dapat dilihat dari hasil wawancara bersama kepala Dinas Kehutanan Kabupaten Aceh Jaya:

"Kita untuk hal SDM masih sangat kurang, sehingga proses pemerintahan kita tidak dapat berjalan dengan baik. seperti yang ada di Dinas Kehutanan Aceh Jaya saat ini masih sangat kurang tenaga-tenaga yang professional dibidangnya" (Muchtar, wawancara 18 Oktober 2020).

Saat ini dapat dilihat bahwa, faktor ekonomilah yang masih tetap menjadi sebagai salah satu faktor utama dalam setiap kegiatan pertambangan. Dengan adanya pertambangan tersebut dapat menambahkan PAD bagi kabupaten, dengan adanya pertambangan tersebut diharapkan mampu memberi pengaruh yang besar bagi kesejahteraan masyarakat yang ikut melakukan penambangan emas sehingga dengan alasan tersebut, pemerintah kabupaten Aceh Jaya memberikan kesempatan bagi masyarakat baik secara perseorangan maupun secara kelompok melalui koperasi-koperasi yang yang sudah dibentuk dapat melakukan proses penambangan Gunong Ujeun.

Dalam hal environmental factor, Seharusnnya selain para penambang, masyarakat yang menetap di sekitar wilayah pertambangan yang memiliki dampak signifikan dari proses penambangan emas di Gunong Ujeun seharusnya juga dapat melaporkan terkait dengan kerusakan lingkungan yang terjadi. Maka dari itu, environmental factor dalam melakukan implementasi kebijakan lebih kepada suatu pengertian tentang lingkungan yang sangat berperan dalam mengefektivitas terhadap proses implementasi kebijakan. Lingkungan dalam hal ini dapat dijadikan sebagai faktor internal maupun eksternal pada saat proses implementasi kebijakan.

Ada beberapa langkah yang harus ditempuh untuk membangun interaksi yang terjalin menjadi lebih baik dalam organisasi pemerintahan. Pertama, saling berkoordinasi sesama instansi pemerintahan terkait, dalam hal ini Dinas perkebunan dan kehutanan kabupaten Aceh Jaya melakukan koordinasi dengan Subbagian pertambangan yang ada di dinas Pekerjaan umum. Masing-masing dinas dapat mengoptimalkan kewenangannya serta melibatkan pihak eksternal dalam hal ini yaitu para pemerhati lingkungan seperti Lembaga Swadaya 
Masyarakat (LSM) yang selama ini sedang berkecimpung dan aktif dalam menangani masalah lingkungan. Selain itu, pihak Gampong dan juga pihak kecamatan juga dirangkul untuk menjalankan perbup tersebut. Seperti yang telah disebutkan dalam Perbup bahwa setiap para penambang harus mendapatkan rekomendasi dari pihak Gampong Panggong dan Camat Krueng Sabee untuk menjadi salah satu para penambang di Gunong Ujeun. Namun, hal yang berbeda terjadi dilapangan, dimana para penambang yang datang ke Gunong Ujeun merupakan masyarakat pendatang dari berbagai daerah bahkan dari pulau Jawa. Hal ini tentunya akan melahirkan konflikkonflik dan ketegangan sosial di dalam masyarakat penambang.

Kehadiran koordinasi yang baik antar instansi pemerintah secara internal ataupun eksternal mampu mendorong lahirnya sinergisitas dalam proses terbentuknya interaksi sosial dalam implementasi kebijakan. Dengan demikian, proses dari implementasi kebijakan dari Perbup tersebut dapat berjalan seperti yang diharapkan, sekaligus juga dapat menghilangkan bentuk disinteraksi yang pernah terjadi antar lembaga pemerintahan yang dapat menimbulkan ketegangan sosial dalam kehidupan masyarakat pertambangan serta dapat meminimalisir terjadinya penolakan terhadap perbup yang telah ditetapkan.

\section{KESIMPULAN}

Berdasarkan hasil penelitian dan pembahasan dapat disimpulkan bahwa implementasi kebijakan pemerintah kabupaten Aceh Jaya dalam hal ini Perbup Nomor 21 Tahun 2011 tentang penataan pertambangan rakyat, dapat dikategorikan belum maksimal hal ini dapat dilihat dari pendekatan teori dari Smith ada empat karakteristik dari Smith belum maksimal dilakukan oleh para implementator Kabupaten Aceh Jaya. Oleh kerenanya, diharapkan kepada pemerintah kabupaten Aceh Jaya untuk dapat melakukan sosialisasi dan mengimplementasikan peraturan yang telah ditetapkan sebagaimana mestinya. Selain itu, pemerintah Kabupaten Aceh Jaya juga diharapkan agar lebih serius dalam menangani berbagai permasalahan pertambangan emas rakyat yang ada di Kabupaten Aceh Jaya sehingga mampu meningkatkan PAD dan juga kesejahteraan bagi masyarakat Kabupaten Aceh Jaya.

\section{REFERENSI}

Aminah, A. (2019). Kebijakan Pemerintah Kabupatenaceh Jaya Dalam Pengelolaan Tambang Emas Rakyatdi Gunong Ujeun. Jurnal Public Policy, 2(2).

Aminah, A. (2017). Tambang Rakyat Rentan Konflik (Studi Kasus Pertambangan Emas Rakyat Di Gunong Ujeun Kabupaten Aceh Jaya). Jurnal Public Policy, 3(2), 183-192.

Aminah, A. (2015). Tambang Rakyat, Berkah Atau Musibah? (Studi Tentang Tambang Emas Rakyat Di Gunong Ujeun Kabupaten Aceh Jaya). Jurnal Public Policy, 3(1).

Andriani, Y., Silitonga, H., \& Wanto, A. (2018). Analisis Jaringan Syaraf Tiruan Untuk Prediksi Volume Ekspor Dan Impor Migas Di Indonesia. Register: Jurnal Ilmiah Teknologi Sistem Informasi, 4(1), 30-40.

Bungin, B. (2007). Penelitian Kualitatif: Komunikasi, Ekonomi, Kebijakan Publik, Dan Ilmu Sosial Lainnya (Vol. 2). Kencana.

Denzin, N. K. (2010). Moments, Mixed Methods, And Paradigm Dialogs. Qualitative Inquiry, 16(6), 419-427
Djajadiningrat, S. T. (2004). Kawasan Industri Berwawasan Lingkungan: Fenomena Baru Dalam Membangun Industri Dan Kawasannya Demi Masa Depan Berkelanjutan. Rekayasa Sains.

Dwijowijoto, Riant Nugroho, (2008), Public Policy ; Teori Kebijakan - Analisis Kebijakan - Proses Kebijakan, Perumusan, Implementasi, Evaluasi, Revisi, Risk Management Dalam Kebijakan Publik, Kebijakan Sebagai The Fifth Estate - Metode Penelitian Kebijakan, Jakarta : Elex Media Komputindo.

Dye, Thomas R. (1992). Understanding Publik Policy, New Jersey: Prentise Hall.

Moleong, L. J. (2010). Methodology Of Qualitative Research. Bandung: Remaja Rosda Karya.

Moleong, L. J. (2010). Metodologi Penelitian Kualitatif (Xxvii). Bandung: Remaja Rosdakarya.

Riant Nugroho. (2012). Public Policy. Pt.Elex Media Komputindo: Kompas Gramedia Jakarta.

Rochmaningrum, F. (2012). Perkembangan Tambang Minyak Blok Cepu Dan Pengaruhnya Terhadap Sosial Ekonomi Masyarakat Desa Ledok Tahun 1960-2004 (Doctoral Dissertation, Universitas Negeri Semarang).

Smith, T. B. (1973). The Policy Implementation Process. Policy Sciences, 4(2), 197-209.

Smith, Thomas B., (1973), The Policy Implementation Process, Policy Sciences 4, Pp. 197 - 209., Elsevier Scientific Publishing Company, Amsterdam - Printed In Scotland.

Sularno, N. D. M. (2019). Lingkungan Obyek Wisata (Studi Deskriptif Tentang Dampak Tambang Emas Di Gunung Tumpang Pitu Terhadap Obyek Wisata Pulau Merah Di Kabupaten Banyuwangi) (Doctoral Dissertation, Universitas Airlangga).

Thoha, M. (2005). Administrasi Dan Kebijakan Publik. Cetakan Pertama. Jakarta: Rineka Cipta.

Wahab, Solichin Abdul, (2006). Analisis Kebijaksanaan: Daari Formulasi Ke Implementasi Kebijaksanaan Negara, Jakarta: Sinar Grafika.

Widagdya, F. P. (2014). Peranan Psak No 33 Pada Perusahaan Pertambangan Di Indonesia. Jurnal Akuntansi Akunesa, 2(3).

Winarno, B. (2007). Kebijakan Publik: Teori Dan Proses. Yogyakarta: Media Pressindo.

Yudhistira, Y., Hidayat, W. K., \& Hadiyarto, A. (2011). Kajian Dampak Kerusakan Lingkungan Akibat Kegiatan Penambangan Pasir Di Desa Keningar Daerah Kawasan Gunung Merapi. Jurnal Ilmu Lingkungan, 9(2), 76-84. 